\title{
Educational Marketing Mix and Student Satisfaction in Private Universities in Dubai
}

\author{
Sara Basyouni \\ School of Marketing Communications, Middlsex University Dubai, knowledge park, Block 16
}

\begin{abstract}
Marketing of higher education has become a strategic competitive tool due to the emergence of private universities. The purpose of this paper is to identify the important factors that influence students' satisfaction at the higher education institutions (HEIs) and to measure the level of students' satisfaction with respect to the educational marketing mix (EMM) being offered by the universities. Data was collected through questionnaires from randomly selected 324 students from Middlesex University and Wollongong University in Dubai. SPSS program was used to analyze the data. The study found that 'People' was the most important factor that influence students' satisfaction level while 'Program' was the least. The satisfaction level of students was high; and this indicates the good performance of the universities in Dubai. The paper recommended conducting a further research that compares between student satisfaction in both public and private universities.
\end{abstract}

Keywords: Student Satisfaction, Educational Marketing Mix, Higher Education, Student's Choice, Dubai.

DOI: $10.7176 / \mathrm{EJBM} / 11-24-15$

Publication date: August $31^{\text {st }} 2019$

\section{Introduction}

The United Arab Emirates (UAE) was established as a federal state on the $2^{\text {nd }}$ of December 1971, with the coalition of six Emirates, Abu Dhabi, Dubai, Sharjah, Ajman, Umm Al Qaiwain, and Fujairah while the seventh Emirate, Ras Al Khaimah, joined them in 1972 (Alhebsi et al., 2015). In 1971, there were no universities at that time in UAE; only 74 schools. After the establishment of the country, the education system was developed based on the British model, though lately, aspects of the US system have been adopted. "For example, the quality assurance standards used at the federal level are based on a US model" (Wilkins, 2010). In a very short period of time, the UAE has established an outstanding and diversified system of higher education (Abou Naaj et al., 2012). The first HEI in UAE was the UAE University. It was established in Al Ain Emirate in 1977 (Wilkins, 2010). According to Sheikh Saud bin Qasimi Foundation for Policy Reseach (2013), higher education in UAE includes three types; public, semi-public, and private universities. As the competition between the private universities is increasing, marketing of higher education has become a strategic tool. The universities should satisfy the students to the maximum to guarantee retaining the students and acquire new ones. This paper will help the HEIs recognize the factors that influence students' satisfaction.

\section{Literature Review \\ 2.1 Educational Marketing}

There has been a considerable amount of debate over whether educational institutions should get involved in marketing. Some literature refused the idea of educational marketing as marketers are profit-oriented and therefore it cannot be applied to higher education (Fosu and Poku, 2014). This indicates that the main goal of the educational institutions would be seeking profit rather than providing education as a social service (Al-Fattal, 2010). The integration of marketing models used by businesses into higher education has been criticized by much debate, especially who the customers of academic institutions are (Boateng, 2015). Some scholars think that students should not be considered as consumers (Fosu and Poku, 2014) as it is not appropriate to discuss this issue and it is even shameful to call students customers (Al-Fattal, 2010). "In the past, marketing has been most widely applied in the business sector. In recent years, however, marketing also has become a major component in the strategies of many non-profit organizations, such as colleges, charities, churches, hospitals, museums, performing art groups and even police departments" (Kotler et al., 1999). On the other hand, Mainardes et al. (2011) argued that the development of the private universities was due to the mass market and public universities' demand. This strengthens the competition among HEIs. And as a result, the higher education sector started to function by a market-based logic. According to Ramachandran (2010), marketing departments now is a must and have unique positions in any HEI's organizational structure. Marketing strategies are perceived as important as finance, human resources, quality assurance and other departments within the institution, if not in some cases more important.

\subsection{Marketing Mix for Education}

"Marketing mix is controllable tools that institutions use to getting appropriate response from their target markets" (Alipour et al., 2012). These tools consist of product, price, place and promotion; known as the "4Ps". 
A version of marketing mix was developed specifically for educational institutions. It consists of 7 elements known as the "7Ps" (Al-Fattal, 2010) where product was placed by "programme" (Fosu and Poku, 2014). Programme is the first element of educational marketing mix. In the context of higher education, study and degree programme are the main product of the university. Therefore, the HEIs should design their own programmes freely to meet their customers' needs and wants and satisfy them (Nedbalová et al., 2014). Many universities have developed a lot of study programmes related to all areas of activity and interest. For example, Harvard University offers variety of study programmes, like Business, Dental, Design, Education, Law, Medical, Public Health, Engineering, Arts and Sciences....etc. (Raţiu and Avram, n.a). Price is the second element of the marketing mix. From the perspective of education, it is defined as the amount of money the student pays to attain education. It includes tuition fees, "grant, scholarship or loan along with such non-financial costs as time, inconveniences and distance" between the institution and the student's place (Fosu and Poku, 2014). The price can be viewed as an economic and psychological factor. From the economic perspective, it determines income and profit, while, from the psychological point of view, it defines values that a product or service offers. It is a quality indicator and has effects on the image and other elements as well (Gajić, 2012). The place element refers to "the system of delivery and channels of service distribution. It deals with making education available and accessible in terms of time and physio-geographical distribution of teaching and learning". It also relates to the convenience of the university's location and access to the students (Fosu and Poku, 2014). The place element includes a Website that enables students to download the learning material anytime (Al-Fattal, 2010). Universities should take into consideration the physical buildings like the appearance, functionality and atmosphere of service space (Gajić, 2012). Promotion in the education sector is defined as the university's ability to communicate with its publics. The promotional mix consists of six elements; advertising, public relations, sales promotion, direct marketing, personal selling and sponsorship. Media, social event, discount on fees, direct mails to the students, outreach activities are all examples of the promotional mix (Nedbalová et al., 2014). Process refers to the way a university does business, and this relates to the whole administrative system. It involves how things happen in an institution, such as the process of management, enrolment, teaching, learning, registration process, examination process, social and even sports activities (Fosu and Poku, 2014). People in marketing mix include all the teaching and administrative staff who are significant in delivering a satisfactory service and attracting students as well as funds. It also includes the university's current and previous students, since the prospective ones usually ask for their opinions and impressions (Sampaio et al., 2012). The HEI should choose its staff wisely as it is believed that the institution's success depends on the attitudes, commitment and skills of the whole workforce rather than any other element (Al-Fattal, 2010). Physical facilities element is believed to be the first impression prospective students have of an institution upon visiting as the builtenvironment and the facilities of the university like technologies used, cleanliness of rooms, carpeting and regular washroom cleaning are often the first thing they see. Not only physical facilities element is connected with the customers' attitudes towards the institution but also it supports the teaching process, for example the use of visual representation and information technologies that simplify and advance the learning process (Al-Fattal, 2010).

\subsection{Students' Choice Models}

Studying students' selection criteria is critical for HEIs to gain an effective understanding of the student market, customers' needs and develop their service quality. Models of student choice emerged in the early 1980s (Kusumawati et al., 2010). Most of the studies that tried to clarify student choice could be included in one of three categories; economic models, status-attainment models and combined models (Maniu and Maniu, 2014). The economic models depend on the rational econometric assumptions done by the prospective students regarding the cost benefit of the university (Beswick, 1973). The status-attainment models are also known as sociological models (Fosu and Poku, 2014). The models suggest that a variety of social and individual aspects like parental encouragement, influence of other people and academic performance lead to educational aspiration (Maniu and Maniu, 2014). The combined models include the most significant indicators from both statusattainment and economic models in students' decision making process (Migin et al., 2015). Chapman model (1981), Jackson model (1982), Hanson and Litten model (1989), Hossler and Gallagher Model (1987) and Kotler and Fox model (1985) are combined models that have become the most widely accepted in the enrollment behavior (Kusumawati et al., 2010). Hossler and Gallagher model reflects the other models, "but creates a simpler yet more conceptual model". It consists of three-stage framework; predisposition, search, and choice. The first stage, predisposition, is the students' decision to attend HEI. It is highly influenced by the students' desire to continue their studies at higher education, in addition to background and the encouragement from their parents (Migin et al., 2015). Secondly, the search stage which indicates the students' learning process about specific universities and their attributes. This stage results in a list of institutions in which the student will apply (Beswick, 1973). The last stage is the choice stage in which the student chooses a specific institution (Hayden, 2000). 
Academic reputation is believed to have a powerful impact on students' college selection process. Many prospective students are aware of the importance of the institution's degree on their marketability; therefore academic merit becomes significant factor in their selection criteria. African American students selected institutions' reputation and availability of major as the two most important factors (Petr and Wendel, 1998). Similarly, a study that was conducted in Malaysia found that the reputation of the university is the strongest evaluative criteria used by students in order to choose their universities (Poole and Ewan, 2010). Students are interested in the outcome. Therefore they choose the university that will help them in finding suitable and respectful career opportunities. Also the location of the institution is considered as an important factor as many students prefer to attend a university that is close to their homes or workplace. It was noted that the location of the college and the geography of its surroundings are critical to students (Kusumawati, 2013).

\subsection{Students' Satisfaction}

"Customer satisfaction is defined as the result of a cognitive and affective evaluation" where comparisons between the customer's expectations and the perceived performance of the product/service are done" (Mostaghel, 2006). In the context of higher education, student satisfaction is defined as a short-term attitude that comes from the student's assessment of the overall college experience (Elliott and Healy, 2001). A lot of studies proved the strong relationship between consumer's satisfaction, loyalty and retention (Angelova and Zekiri, 2011). HEIs benefit from the satisfied students as they will remain for a longer period, might enroll again for extra studies and spread positive words about the organization. On the other hand, dissatisfied students might quit the university or the college and enroll in another one, complain about it and engage in negative word of mouth (Fosu and Poku, 2014). Therefore, the idea of students' satisfaction and loyalty became one of their main goals. The definition of consumers is crucial for the HEIs; it was divided into students, employees, employers, public, industry and wider community, however, students were considered to be the most important customers (Temizer and Turkyilmaz, 2012). The university's product is not only academic program but a sum of students' social, physical, academic and spiritual experiences (Mavondo et al., 2004). In other words, for many students, the studying process is not only related to the acquirement of theoretical knowledge and certain skills, but also related to personal growth and social development (Newell, 2015).

HEIs always seek for students' opinion about everything in the academic life, mainly by using questionnaires (Douglas et al., 2006). To understand the students' opinions and attitudes and measure their satisfaction level regarding the teaching process, institution, staff, facilities...etc., a coherent student satisfaction model is needed (Jurkowitsch et al., 2006). The ServQual model is one of the most famous models in measuring customer satisfaction. It was developed by Parasurman, Zeithaml and Berry. It suggests that customers are asked to record their satisfaction rate with a number of traits using a scale measuring their expectations and then they should fill out another one measuring the perceived performance. Another scale that examines the importance of each feature to the consumer was then introduced to the model (Letcher and Neves, n.d ). However, the ServQual model had a lot of criticisms. Taking the criticisms into consideration, some other models were introduced based only on a single scale asking about the perceived performance and has nothing to do with the expectations like the ServPerf model (Douglas et al., 2006). The Higher Education Funding Council for England (HEFCE) has developed a National Student Survey. This survey targets students at their last year in order to know their opinions and views on a number of factors of teaching, assessment, support and courses offered by their university. The findings will be used by the government and funding sources to develop "league tables of university performance". The ranking of any university in these tables will definitely affect its image (Douglas et al., 2006). According to Sampaio et al. (2012) image has a strong effect on acquiring and attracting new students as well as retaining the current ones.

\subsection{Previous Studies and Findings}

Two separate studies were done to compare between the opinions of the administrators and the students of universities and colleges regarding the most important factors needed for a successful marketing strategy for an educational institution. The findings of the administrators sample showed that "market image" is the most important factor that can help the university or college gain a competitive advantage followed by "technology and people" then "campus and courses". However, students' sample showed that "future employment" is the most important factor (Mazzarol et al., 2001).Wagner and Fard (2009) concluded that "cost of education, degree (content and structure), physical aspect and facilities, value of education, and institutional information have significant relationship with students' intention to study at a HEI". Also, the authors confirmed that there is relationship between influencers like family, friends, peers and students' intention to study at a specific HEI. Another study showed that right course, availability of computers, library facilities, calm and self-study areas, good teaching, comfortable public transportation in the city and friendly attitude towards the students have the strongest impact on students' decision to enroll at a certain university (Douglas et al., 2006). 


\section{Research methodology}

The research design for this study is descriptive due to the fact that it seeks to identify the factors that influence students' satisfaction with private universities in Dubai. The study targeted undergraduate and postgraduate students studying at two private universities in Dubai; Middlesex University and Wollongong University. Both females and males at different ages, year of study and nationality were targeted. Three hundred twenty four elements have been questioned. The researcher administered the questionnaire to ten undergraduate and postgraduate students before administering it to the larger sample to make sure of the efficiency of the questions. The length of time it took them to complete the questionnaire was noted. It took from 12 to 15 minutes to complete the survey. After then, they were asked about their feedback concerning the validity and reliability of the questions, also if there was anything missing from the questionnaire. Based on their comments and feedback, a number of questions were modified. This study used simple random sampling. "In this case, all members of the population have a known and equal chance of being included in the sample "(Proctor, 2005). The study used SPSS program to analyze the data. Results were presented in the form of tables and detailed description.

The questionnaires were of three sections A, B and C. Section 'A' was mainly designed to collect the demographic data of the students. Section 'B' focused on the factors that influence students' satisfaction using 5 point Likert Scale. Section 'C' measured students' satisfaction level with the services being offered by their universities.

\section{Discussion of Findings}

The participants were selected from all level of studies including postgraduates and from different colleges and departments of the two universities. Out of 324 questionnaires, the respondents from Middlesex University Dubai were 178 representing 55\% and 146 from Wollongong University Dubai representing 45\%. The males were 176 representing $54 \%$ of the total and females were 147 representing $46 \%$. More than half of the students are Asians with almost 73\% followed by Arabs with 10\% while Latin Americans and North Americans represent the least percentage $1 \%$. This is due to the fact that the highest expat population in UAE goes to India by 27.49\%, followed by Pakistan 12.69\%, then Bangladesh 7.4\%, then Philippines 5.56\%, Iran 4.76\% and Egypt 4.23\%. Emiratis represent $11.48 \%$ from UAE population (Blogger, 2019). There was a great difference between the full time and part time students where the FT students exceeded the PT by 276 students. The first group represented 93\% and the second one 7\%. Middle year(s) students represented 35\% followed by final and first year students who have the same percentage $23 \%$ and then postgraduate students with $19 \%$.

Section ' $\mathrm{B}$ ' concentrated on the factors that affect students' satisfaction with respect to the educational marketing mix or the 7 Ps. It used the 5 point Likert Scale questions ranging from ' 1 ' very important to ' 5 ' not important at all. Each element was divided into sub-elements. 'Programme/learning experience' was divided into variety of programmes offered, study load, number of students in class and study materials and books. 'Price' came in grant, loan or scholarship being offered by the university and if the fees paid is worthwhile investment. Availability to download learning materials, university location in town and multiple campuses came under 'Place'. 'Promotion' was presented in university advertising (TV, radio, newspaper, outdoor...etc), informative university website, social events and outreach activities. 'Process' was divided into organized registration process and organized examination process. 'Teaching and non-teaching staff' or 'People' element came in expert tutors and lecturers, high qualified teaching staff, student-staff relationships, teaching staff friendly attitude towards student, employees dressing/uniform, helpful \& knowledgeable admission counsellors, department response to students' requirements, and social life at the university. University transportation/ buses (cleanliness, comfort, runs on time), interior decorations, exterior decorations, accommodation facilities, cleanliness of buildings, well-equipped library, school furniture, laboratory facilities, parking, technology and internet facilities, places to study on campus and availability of text books came under 'Physical facilities'.

Table 4.1 Students' importance level of EMM

\begin{tabular}{|l|c|c|c|c|}
\hline Educational marketing mix satisfaction & $\mathrm{N}$ & Mean & Std. Deviation & Level of importance (\%) \\
\hline People & 318 & 3.6765 & 1.01179 & $74 \%$ \\
Process & 318 & 3.6352 & 1.08501 & $73 \%$ \\
Physical facilities & 319 & 3.6136 & 0.92845 & $72 \%$ \\
Price & 319 & 3.5313 & 1.10130 & $71 \%$ \\
Promotion & 319 & 3.4929 & 0.94115 & $70 \%$ \\
Place & 319 & 3.4924 & 1.01959 & $70 \%$ \\
Program & 320 & 3.4237 & 0.85940 & $68 \%$ \\
\hline
\end{tabular}

It was found that "Teaching and non-teaching staff" or "People" got the highest level of importance (74\%), followed by "Process" (73\%), then "Physical Facilities" (72\%), however "Program" had the least level of importance (68\%). Since the difference between the levels of importance of the 7 Ps is slight, we can conclude that all of them are important and affect the level of students' satisfaction. The findings of this paper is in line with the works of Hameed and Amjad (2011), Tessema et al.( 2012), Sohail and Saeed (2003) and Parahoo et al. 
(2013). Sohail and Saeed (2003) for instance, found out that contact personnel is the most important factor that influence students' satisfaction. Also, physical environment, cleanliness, classrooms, lighting and appearance of buildings affect the level of satisfaction. Hameed and Amjad (2011) proved that faculty, advisory staff and classes have a significant impact on Pakistani students' college experience which leads to students' satisfaction. Tessema et al.( 2012) confirmed that academic advising, capstone experience, overall college experience, quality of instruction, and preparation for career scored the highest five factors in affecting students' satisfaction in "mid-sized Midwestern U.S university". "Researchers empirically developed and tested a multiple linear regression model of student satisfaction at a university in Dubai". The findings showed that the branding and interactions of administrative staff with students have positive relationship with student satisfaction. Logit model was used by a different study that aimed to examine student satisfaction with their university campus located in UAE. Quality of teaching, availability of resources and effective use of technology were the main aspects influencing student satisfaction (Parahoo et al., 2013).

Table 4.2 First year students' importance level of EMM

\begin{tabular}{|l|c|c|c|c|}
\hline Educational marketing mix satisfaction & Mean & $\mathrm{N}$ & Std. Deviation & Level of importance (\%) \\
\hline People & 3.7244 & 75 & 1.13131 & $74 \%$ \\
Physical facilities & 3.6689 & 74 & 1.01576 & $73 \%$ \\
Promotion & 3.6554 & 74 & 0.99028 & $73 \%$ \\
Process & 3.6486 & 74 & 1.17837 & $73 \%$ \\
Place & 3.5614 & 74 & 1.10284 & $71 \%$ \\
Program & 3.4662 & 74 & 1.01134 & $69 \%$ \\
Price & 3.3446 & 74 & 1.14654 & $67 \%$ \\
\hline
\end{tabular}

The researcher compared between the undergraduate students (who were classified into three groups; first, middle, and last year students) and the postgraduate ones. It was found that students at their first year at college/university are affected the most by the teaching and non-teaching staff $74 \%$ while price got the least attention. Physical facilities, promotion and process got the same percentage $73 \%$.

Table 4.3 Middle year(s) students' importance level of EMM

\begin{tabular}{|l|c|c|c|c|}
\hline $\begin{array}{l}\text { Educational marketing } \\
\text { mix satisfaction }\end{array}$ & Mean & $\mathrm{N}$ & Std. Deviation & $\begin{array}{c}\text { Level of } \\
\text { importance (\%) }\end{array}$ \\
\hline People & 3.6976 & 111 & .93451 & $74 \%$ \\
Physical facilities & 3.6745 & 111 & .89393 & $73 \%$ \\
Process & 3.6712 & 111 & 1.03242 & $73 \%$ \\
Price & 3.5901 & 111 & 1.06001 & $72 \%$ \\
Promotion & 3.5248 & 111 & 0.93539 & $70 \%$ \\
Place & 3.4688 & 111 & 0.99914 & $69 \%$ \\
Program & 3.4099 & 111 & 0.76262 & $68 \%$ \\
\hline
\end{tabular}

Regarding students studying at their middle year(s), "people" got the highest percentage with 74\% followed by "physical facilities" and "process" with the same percentage $73 \%$ and then "price" $72 \%$ while "program" got the least, $68 \%$.

Table 4.4 Final year students' importance level of EMM

\begin{tabular}{|l|c|c|c|c|}
\hline $\begin{array}{l}\text { Educational marketing } \\
\text { mix satisfaction }\end{array}$ & Mean & $\mathrm{N}$ & Std. Deviation & $\begin{array}{c}\text { Level of } \\
\text { importance (\%) }\end{array}$ \\
\hline Process & 3.6438 & 73 & 1.10391 & $73 \%$ \\
People & 3.5874 & 73 & 1.00644 & $72 \%$ \\
Price & 3.5548 & 73 & 1.09786 & $71 \%$ \\
Physical facilities & 3.4795 & 74 & 0.89207 & $70 \%$ \\
Place & 3.4425 & 73 & 0.96170 & $69 \%$ \\
Program & 3.3997 & 74 & 0.84580 & $68 \%$ \\
Promotion & 3.3904 & 73 & 0.87697 & $68 \%$ \\
\hline
\end{tabular}

For final year students, "process" is the factor that affects their satisfaction the most with $73 \%$ followed by "people" $72 \%$ then "price" $71 \%$. "Promotion" got the least with $68 \%$ 
Table 4.5 Postgraduate students' importance level of EMM

\begin{tabular}{|l|c|c|c|c|}
\hline $\begin{array}{l}\text { Educational marketing } \\
\text { mix satisfaction }\end{array}$ & Mean & N & $\begin{array}{c}\text { Std. Devia } \\
\text { Tion }\end{array}$ & $\begin{array}{c}\text { Level of } \\
\text { importance (\%) }\end{array}$ \\
\hline People & 3.6863 & 59 & 1.01715 & $74 \%$ \\
Price & 3.6230 & 61 & 1.12419 & $72 \%$ \\
Physical facilities & 3.5980 & 60 & 0.92814 & $72 \%$ \\
Process & 3.5417 & 60 & 1.05883 & $71 \%$ \\
Place & 3.5111 & 61 & 1.03903 & $70 \%$ \\
Program & 3.4262 & 61 & 0.86162 & $69 \%$ \\
Promotion & 3.3607 & 61 & 0.95364 & $67 \%$ \\
\hline
\end{tabular}

From table 4.5, we can see that postgraduate students' satisfaction level is affected the most by the teaching and non-teaching staff followed by "price". We can observe that this is the first time "price" comes in the second place with $72 \%$. Maybe, this is due to; some of the postgraduate students pay for themselves. Although, it got the same percentage as the middle year(s) students had.

We can conclude that almost all of the four groups (first year, middle year(s), last year and postgraduates) are influenced the most by "people". However, it had the second place for students studying at their final year, yet with high percentage $72 \%$. Obviously, all students do care about student-staff relationship, the professionalism of lecturers, staff's friendly attitude, department's response to their requirements, expert admission counsellors and the social life at the campus the most. Therefore, universities should hire competent and high calibre lecturers to be able to meet students' needs. Recruiting expert and knowledgeable teaching and non-teaching staff should come in the first place of the university's concerns. Since there is no such big difference between the four groups, we can conclude that different stages of study do not affect students' EMM importance level.

H1: There are significant differences among perceived educational marketing mix that extremely satisfy students according to the year of study.

Perceived Educational Marketing Mix Table 4.6

\begin{tabular}{|r|c|c|c|c|}
\hline Year of study & Mean Rank & Mean & $\mathrm{N}$ & Std. Deviation \\
\hline first year & 154.86 & 2.39 & 76 & 1.05 \\
middle year(s) & 160.13 & 2.37 & 113 & 0.86 \\
final year & 171.26 & 2.52 & 74 & 0.87 \\
Postgraduate & 165.78 & 2.47 & 61 & 0.91 \\
Total & & 2.43 & 324 & 0.92 \\
\hline
\end{tabular}

Test Statistics

Table 4.7

\begin{tabular}{|c|c|}
\hline & Perceived educational Marketing Mix \\
\hline Chi-Square & 1.514 \\
Df & 3 \\
Asymp. Sig. & 0.679 \\
\hline
\end{tabular}

a. Kruskal Wallis Test

b. Grouping Variable: Year of study

Applying Kruskal Wallis test, the alternative hypothesis is not confirmed ( $\mathrm{p}$-value $=0.679>0.05, \mathrm{df}=3$ ), meaning that there is no significant difference between scores of Educational marketing mix among the four groups of students divided according to their year of study (first year, middle year (s), final year, and postgraduates), in another words we can say that students' perceived EMM have slight differences according to the year of study.

Table 4.8 Student Satisfaction

\begin{tabular}{|l|c|c|c|c|}
\hline \multicolumn{1}{|c|}{ Year of study } & Mean & N & Std. Deviation & $\begin{array}{c}\text { Level of } \\
\text { satisfaction (\%) }\end{array}$ \\
\hline first year & 3.9315 & 73 & 1.07146 & $79 \%$ \\
middle year(s) & 3.6606 & 109 & 1.04722 & $73 \%$ \\
final year & 3.4306 & 72 & 1.03225 & $69 \%$ \\
Postgraduate & 4.0172 & 58 & 0.96412 & $80 \%$ \\
Overall & $\mathbf{3 . 7 3 7 2}$ & $\mathbf{3 1 2}$ & $\mathbf{1 . 0 5 2 4}$ & $\mathbf{7 5 \%}$ \\
\hline
\end{tabular}

In section ' $\mathrm{C}$ ', the researcher asked the students to rank their satisfaction level using 5 point Likert scale question where ' 1 ' very satisfied and ' 5 ' very dissatisfied based on the services offered by the university mentioned in section 'B'. The overall satisfaction level of students in private universities in Dubai scored $75 \%$. Postgraduate students had the highest satisfaction level, $80 \%$. Followed by students at their first year of study 
$79 \%$, then students at their middle year(s) of study $73 \%$, however, students in the final stage of study had the lowest satisfaction level; $69 \%$. The overall percentage $75 \%$ is considered high. We can conclude that the private universities in Dubai are on a good standards and offer good services to the students. This indicates that they have adopted service marketing strategies in meeting the needs of their students. According to the table 4.6, looking at first, middle and last year of study students, we can say that satisfaction decreases over time. However, postgraduates scored the highest level of satisfaction. Sometimes postgraduate students are considered as new comers (first year). This might be the rationale behind the similarity of postgraduates and first year students' satisfaction level; however this might need a further research.

\section{Conclusion}

The paper has accomplished its objectives. The findings show that students are influenced the most by the teaching and non-teaching staff. This includes the qualifications of the teaching staff, friendly attitude towards students, dressing of employees, personal appearance, expert lecturers, department's response to students' requirements and the social life at the campus. How things are organized and carried out like the process of examination, enrolment and teaching came in the second place. University's facilities like transportation, accommodation, well-equipped library, interior and exterior decorations and parking came in the third place. Although there were slight differences between the 7 elements, thus we can say that all of the EMM affect the satisfaction level of the students. Comparisons between students at different stage of study; first year, middle(s) year, last year and postgraduate students were done to identify the importance level of EMM of each group. Almost all groups ranked 'People' as the most influential factor except for students studying at the final year. Identifying the satisfaction level of the students was the second objective of the paper. Results showed that $75 \%$ of the students are satisfied with the services being offered by the universities. This percentage is considered high, which indicates the good performance of the private universities in Dubai. The paper recommends for further research, comparisons between students' satisfaction level at public and private universities.

\section{References}

Abou Naaj, M., Nachouki, M. \& Ankit, A. 2012. Evaluating Student Satisfaction with Blended Learning in a Gender-Segregated Environment. Journal of Information Technology Education:, vol. 11, pp. 185-200.

Al-Fattal, A. 2010. Understanding Student Choice of University and Marketing Strategies in Syrian Private Higher Education.

Alhebsi, A., Pettaway, L. D. \& Waller, L. 2015. A History of Education in the United Arab Emirates and Trucial Sheikdoms. THE GLOBAL eLEARNING JOURNAL, 4, 2-6.

Alipour, M., Aghamohammadi, A., Ahmadi, R. \& Hoseini, S. H. 2012. A New Educational Marketing Mix: The 6ps for Private School Marketing in Iran. Research Journal of Applied Sciences, Engineering and Technology, 4, 4314-4319.

Angelova, B. \& Zekiri, J. 2011. Measuring Customer Satisfaction with Service Quality Using American Customer Satisfaction Model (ACSI Model). International Journal of Academic Research in Business and Social Sciences, 1, 232-258.

Beswick, R. L. K. 1973. A Study of factors associated with student choice in the university selection process. Masters thesis, University of Lethbridge. Cengiz, E. 2010. MEASURING CUSTOMER SATISFACTION:MUST OR NOT? Journal of Naval Science and Engineering, 6, 76-88.

Blogger, G. (2019). United Arab Emirates Population Statistics (2019). [Blog] GMI. Available at: https://www.globalmediainsight.com/blog/uae-population-statistics/ [Accessed 28 Aug. 2019].

Boateng, A. (2015). Branding Public Universities through Advertising: A Study of Two Public Universities in Ghana. Journal of Developing Societies, 5(21), p.44.

Douglas, J., Douglas, A. \& Barnes, B. 2006. Measuring student satisfaction at a UK university. Quality Assurance in Education, 14, 251-267.

Elliott, K. M. \& Healy, M. A. 2001. Key Factors Influencing Student Satisfaction Related to Recruitment and Retention. Journal of Marketing for Higher Education, 10, 1-11.

Fosu, F. F. \& Poku, K. 2014. Exploring the Factors That Influence Students' Choice of Higher Education in Ghana. European Journal of Business and Management, 6, 209-220.

Gajić, J. 2012. Importance of marketing mix in higher education institutions Singidunum journal of Applied Sciences 9, 29-41.

Hameed, A. \& Amjad, S. 2011. Students' Satisfaction in Higher Learning Institutions: A CaseStudy of COMSATS Abbottabad, Pakistan Iranian Journal of Management Studies (IJMS), 4, 63-77.

Hayden, M. L. 2000. Factors that influence the college choice process for african american students. MASTERS OF ARTS IN EDUCATION in Educational Leadership and Policy Studies, State University.

Jurkowitsch, S., Vignali, C. \& Kaufmann, H. 2006. A Student Satisfaction Model For Austrian Higher Education 
Providers Considering Aspects Of Marketing Communications. Innovative Marketing, 2, 9-23.

Kotler, P., Armstrong, G., Saunders, J. and Wong, V. (1999). Principles of marketing. 8th ed. Prentice Hall Europe, pp.8-11.

Kusumawati, A. 2013. A Qualitative Study of the Factors Influencing Student Choice:The Case of Public University in Indonesia. Journal of Basic and Applied Scientific Research, 3, 314-327.

Kusumawati, A., Yanamandram, V. K. \& Perera, N. 2010. University marketing and consumer behaviour concerns: the shifting preference of university selection criteria in Indonesia.

Letcher, D. W. \& Neves, J. S. n.d Determinants of undergraduate business student satisfaction Research in Higher Education Journal, 1-26.

Mainardes, E. W., Alves, H., Raposo, M. \& de Souza Domingues, M. J. C. 2011. Marketing in higher education: A comparative analysis of the Brazil and Portuguese cases. International Review on Public and Nonprofit Marketing, 9, 43-63.

Maniu, I. \& Maniu, G. C. 2014. A Model Of Students' University Decision-Making Behavior. Practical Application of Science, 2, 431-436.

Mavondo, F. T., Tsarenko, Y. \& Gabbott, M. 2004. International and Local Student Satisfaction: Resources and Capabilities Perspective. Journal of Marketing for Higher Education, 14, 41-60.

Mazzarol, T., Soutar, G. N. \& Thein, V. 2001. Critical Success Factors in the Marketing of an Educational Institution: A Comparison of Institutional and Student Perspectives. Journal of Marketing for Higher Education, 10, 39-57.

Migin, M. W., Falahat, M. \& Khatibi, A. 2015. Conceptualizing the Decision Making Process of International Students in Higher Education International Journal of Business and Social Science, 6, 119-126.

Mostaghel, R. 2006 Customer Satisfaction: service quality in online purchasing in Iran. MSc Joint PROGRAM IN MARKETING AND ELECTRONIC COMMERCE, Luleå University of Technology.

Nedbalová, E., Greenacre, L. \& Schulz, J. 2014. UK higher education viewed through the marketization and marketing lenses. Journal of Marketing for Higher Education, 24, 178-195.

Newell, G. 2015. Assessing Property Student Satisfaction with their Property Education Experience in an Australian University. Pacific Rim Property Research Journal, 19, 133-149.

Parahoo, S. K., Harvey, H. L. \& Tamim, R. M. 2013. Factors influencing student satisfaction in universities in the Gulf region: does gender of students matter? Journal of Marketing for Higher Education, 23, 135-154.

Petr, C. L. \& Wendel, F. C. 1998. factors influencing college choice by out-of-state students Journal of Student Financial Aid, 28, 29-40.

Poole, D. \& Ewan, C. 2010. Academics as part-time marketers in university offshore programs: an exploratory study. Journal of Higher Education Policy and Management, 32, 149-158.

Proctor, T. (2005). Essentials of Marketing Research. 3rd ed. England: Pearson Education Limited, p.115.

Ramachandran, N. T. 2010. Marketing framework in higher education. International Journal of Educational Management, 24, 544-556.

Raţiu, M. \& Avram, E. n.a. Optimizing the Marketing Mix: An Essential Element in Developing Competitive Strategies in the Field of Higher Education. Romanian Economic and Business Review, Vol. 8, No. 1, 57-56.

Sampaio, C. H., Perin, M. G., Simões, C. \& Kleinowski, H. 2012. Students' trust, value and loyalty: evidence from higher education in Brazil. Journal of Marketing for Higher Education, 22, 83-100.

Sheikh Saud bin Saqr Al Qasimi Foundation for Policy Research, (2013). Education in the United Arab Emirates and Ras Al Khaimah. Ras Al Khaimah - United Arab Emirates: Sheikh Saud bin Saqr Al Qasimi Foundation for Policy Research, pp.5-10.

Sohail, M. S. \& Saeed, M. 2003. Private higher education in Malaysia: students' satisfaction levels and strategic implications. Journal of Higher Education Policy and Management, 25, 173-181.

Temizer, L. \& Turkyilmaz, A. 2012. Implementation of student satisfaction index model in higher education institutions. Procedia - Social and Behavioral Sciences [Online], 46

Tessema, M. T., Ready, K. \& Yu, W. W. 2012. Factors Affecting College Students' Satisfaction with Major Curriculum: Evidence from Nine Years of Data. International Journal of Humanities and Social Sciences, 2, $34-44$.

Wagner, K. \& Fard, P. Y. 2009. Factors Influencing Malaysian Students' Intention to Study at a Higher Educational Institution. E-Leader Kuala Lumpur 1, 4-20.

Wilkins, S. 2010. Higher education in the United Arab Emirates: an analysis of the outcomes of significant increases in supply and competition. Journal of Higher Education Policy and Management, 32, 389-400. 